\title{
Comparative evaluation of properties of a clay based ceramic shaped via four techniques
}

\section{(Avaliação comparative de propriedades de uma cerâmica à base de argila conformada por quatro técnicas)}

\author{
C. I. Torres ${ }^{1 *}$, N. M. Rendtorff ${ }^{1,2}$, M. Cipollone ${ }^{2,3}$, E. F. Aglietti ${ }^{1,2}$, G. Suárez ${ }^{1,2}$ \\ ${ }^{1}$ Centro de Tecnología de Recursos Minerales y Cerámica (CIC PBA-CONICET La Plata) Con Centenario y 506 M.B. \\ Gonnet (1897), Buenos Aires, Argentina \\ ${ }^{2}$ Universidad Nacional de La Platal, Facultad de Ciencias Exactas, Departamento de Química, 47 y 115, \\ La Plata 1900 Buenos Aires, Argentina \\ ${ }^{3}$ Y-TEC SA, Química Analítica, Ensenada, Argentina
}

\begin{abstract}
The results of qualitative and quantitative properties of clay based ceramic are presented in this work. Four different shaping methods and sintering temperatures were used to understand their influence in the final properties of a ceramic material formulated using kaolinite clay and calcined alumina. This material can be used as a structural ceramic for different applications, and there is no pre-established relation between the forming method and the final sintered properties. Forming methods used to prepare the samples were uniaxial pressing (a batch process that allows application in dry samples), extruding (a continuous process that requires moisture), slip casting (a process that allows to shape complex ceramic ware), and lamination (a batch process that requires moisture). Sintering temperatures were in the range of 1100 and $1400{ }^{\circ} \mathrm{C}$. In order to compare how properties behave as the shaping method and sintering temperature change, textural properties, shrinkage, porosimetry, phase composition and mechanical strength were evaluated and analyzed. Scanning electron microscopy and microtomography were employed for analyzing and comparing the developed microstructures. Differences in the resulting properties are explained in terms of the developed crystalline phases and microstructure.
\end{abstract}

Keywords: clay based ceramics, shaping, sintering, properties.

\section{Resumo}

Resultados das propriedades qualitativas e quantitativas de cerâmica à base de argila são apresentados neste trabalho. Foram utilizados quatro diferentes métodos de conformação e temperaturas de sinterização para entender suas influências nas propriedades finais de um material cerâmico formulado usando argila caulinítica e alumina calcinada. Este material pode ser usado como cerâmica estrutural para diferentes aplicações, e não há relação pré-estabelecida entre o método de conformação e as propriedades sinterizadas finais. Os métodos de conformação utilizados para preparar as amostras foram prensagem uniaxial (processo em batelada que permite a aplicação em amostras secas), extrusão (processo contínuo que requer umidade), colagem (processo que permite moldar produtos cerâmicos complexos) e laminação (processo em batelada que requer umidade). As temperaturas de sinterização foram na faixa de 1100 e $1400{ }^{\circ} \mathrm{C}$. Para comparar como as propriedades se comportam à medida que o método de moldagem e a temperatura de sinterização são alterados, as propriedades de textura, retração, porosimetria, composição de fases e resistência mecânica foram avaliadas e analisadas. Microscopia eletrônica de varredura e microtomografia foram empregadas para analisar e comparar as microestruturas desenvolvidas. As diferenças nas propriedades resultantes são explicadas em termos das fases cristalinas desenvolvidas e da microestrutura.

Palavras-chave: cerâmicas à base de argila, conformação, sinterização, propriedades.

\section{INTRODUCTION}

The sintered properties of ceramics depend on many factors like mineralogy and granulometry of the components, raw materials, shaping method, sintering temperature, thermal gradient and type of furnace, among other parameters [1-6]. Ceramic processing parameters to be optimized include production capacity, clay shape, practicality, cost,

*camila_torres.o@cetmic.unlp.edu.ar etc. The influence of the different manufacturing variables could be better understood by analyzing the behavior of the sintered properties. Shaping methods have a direct effect on textural and mechanical properties, shrinkage and microstructure of the sintered material [7]. Processing methods of traditional ceramics are: i) dry (less than $4 \% \mathrm{w} / \mathrm{w}$ of water) or wet pressing, which are used for tiles and for which higher-pressure leads to higher densities; ii) extruding (at atmospheric pressure or vacuum), used for bricks and roof tiles and where in some cases the use of plasticisers is 
required; iii) slip casting, used for tableware and vanity ware where the use of plasticisers is required; iv) lamination, used in manufacturing of ceramic multilayer device [6].

Previous works focused on the effect of different industrial shaping methods of clays (pressing, extruding and slip casting). These studies have been performed at laboratory scale and their aim was to understand the differences in the final properties reached using each processing method. There are studies on pressing and extruding methods and their effect on flexural strength, where higher values were found for pressing [8]. Microstructure and porosity have been analyzed for each forming method, and a suitable classification with respect to water absorption has been defined for several applications [9]. A comparative study on the effect of dry pressing, slip casting and extruding found higher densification when extruding, while intermediate processing performance was observed for dry pressing [10]. Transformations of clay minerals during heating are complex and there is no simple relationship between the behaviors of ceramic processing and sintering properties. The sintering properties have been a subject of study by several authors; their aim has been analyzing the mineralogical, chemical and physical characteristics of kaolinitic clay minerals [1115]. In view of its different industrial applications, special attention should be paid to the kaolinitic clay system and the relation between the processing of raw materials and the sintering properties.

The purpose of this study is to understand the effect of the shaping method and sintering temperature on the final properties of clay-alumina ceramic materials with industrial applications. For this purpose, a mixture of kaolinitic clay and calcined alumina were used to obtain at laboratory a material with a high degree of mullite formation. Different processing techniques such as uniaxial pressing, extruding, lamination and slip casting were chosen due to their extended use on the forming processes for traditional ceramics. The properties of the ceramic specimens were determined as a function of the shaping method and heat treatment.

\section{MATERIALS AND METHODS}

Raw materials: the clay mixture under study had a composition of $80 \%$ commercial kaolinite clay (blend) provided by Piedra Grande (Neuquén, Argentina), and 20\% alumina A2G (Almatis, $\alpha$-alumina $99.1 \%, \mathrm{D}_{50} 5 \mu \mathrm{m}$ ). The chemical composition, crystallochemistry, granulometry and shrinkage properties of the clay are shown in Table I.

Shaping: the analyzed samples were shaped in prismatic bars by four different techniques: uniaxial pressing $(\mathrm{P})$, extruding (E), lamination (L) and slip casting (S). The mixture preparation for pressing was made by ball milling for $24 \mathrm{~h}$. The milling parameters were $2 \mathrm{~cm}$ porcelain balls with water added up to a third of the total volume of the mill. The wet mixture was removed and left $96 \mathrm{~h}$ in oven at $110{ }^{\circ} \mathrm{C}$ to dry. The dry mixture was again ball milled for $24 \mathrm{~h}$, with the same conditions, for micronizing and sieving in order to conserve the fraction smaller than 150
Table I - Chemical analysis, XRD and characteristics of the clay.

[Tabela I - Análise química, DRX e características da argila.]

\begin{tabular}{|c|c|}
\hline \multicolumn{2}{|l|}{ Chemical analysis (wt \%) } \\
\hline $\mathrm{SiO}_{2}$ & 55.04 \\
\hline $\mathrm{Al}_{2} \mathrm{O}_{3}$ & 28.58 \\
\hline $\mathrm{Fe}_{2} \mathrm{O}_{3}$ & 4.13 \\
\hline $\mathrm{MgO}$ & 0.72 \\
\hline $\mathrm{K}_{2} \mathrm{O}$ & 2.27 \\
\hline $\mathrm{TiO}_{2}$ & 0.81 \\
\hline $\mathrm{CaO}$ & 0.21 \\
\hline Loss on ignition $\left(110^{\circ} \mathrm{C}\right.$ dried samples $)$ & 0.36 \\
\hline \multicolumn{2}{|l|}{ Crystallochemistry composition (wt\%) } \\
\hline Quartz & 25 \\
\hline Kaolinite & 55 \\
\hline Illite & 13 \\
\hline Plagioclase & 2 \\
\hline Feldspar & 5 \\
\hline \multicolumn{2}{|l|}{ Particle size } \\
\hline $\mathrm{D}_{50}(\mu \mathrm{m})$ & 2.53 \\
\hline \multicolumn{2}{|l|}{ Shrinkage after firing $(\%)$} \\
\hline $1200{ }^{\circ} \mathrm{C}$ & $\sim-9$ \\
\hline $1400{ }^{\circ} \mathrm{C}$ & $\sim-5$ \\
\hline
\end{tabular}

$\mu \mathrm{m}$. Dry pressing bars were made in uniaxial press at 100 $\mathrm{MPa}$; the dimensions reached were $50 \times 8 \times 7 \mathrm{~mm}$ with an average weight of $5.7 \mathrm{~g}$. The clay mixture for extruding, lamination and slip casting was made by means of a slurry preparation with $40 \%$ water, $60 \%$ solids and $0.4 \mathrm{~g}$ of sodium silicate as deflocculant per $100 \mathrm{~g}$ of solids. Ball milling for $2 \mathrm{~h}$ was performed to achieve good homogenization of the mixture. For extrusion and lamination, the slurry was dried to the plastic state in order to achieve a good workability of the paste in a plaster mold. Operating the extruder, at low pressures and with no vacuum, a tape like paste was obtained and then cut to prismatic bars. The samples were dried and rectified to achieve dimensions of $45 \times 7 \times 7 \mathrm{~mm}$, with an average weight of $5.0 \mathrm{~g}$. For lamination, the metal cylinder was set at $4 \mathrm{~mm}$. A laminated paste with uniform thickness was obtained and then cut to prismatic bars. The samples were dried and rectified to achieve dimensions of $50 \times 4 \times 6 \mathrm{~mm}$, with an average weight of $3.0 \mathrm{~g}$. For slip casting the slurry was poured directly into a plaster mold; a constant feeding was set to prevent remain hollow. The dimensions achieved were $50 \times 8 \times 8 \mathrm{~mm}$, with an average weight of $6.0 \mathrm{~g}$.

Sintering conditions: the samples were sintered in a ramp rate of $5{ }^{\circ} \mathrm{C} \cdot \mathrm{min}^{-1}$, with a holding time of $1 \mathrm{~h}$ at 1100,1200 , 1300 or $1400{ }^{\circ} \mathrm{C}$, in an electric furnace and atmospheric air. 
Characterization: XRD (X-ray diffraction) analysis and quantification by the Rietveld method were performed with a Philips XRD diffractometer (PW3710) with $\mathrm{CuK \alpha}$ radiation $(\lambda=1.5418 \AA)$ and Ni filter at $40 \mathrm{kV}$ and $35 \mathrm{~mA}$ in the range from 5 to $70^{\circ}$, with step of $0.04^{\circ}$ and a permanence of $2 \mathrm{~s} / \mathrm{step}$. The apparent density and porosity of the green samples were measured by Archimedes method in kerosene. After sintering the samples, shrinkage percentage was measured over the length of each of the shaped samples. The apparent porosity and density were measured by Archimedes method in water. For testing mechanical strength, three-point bending was carried out in a universal testing machine (JJ T22K Instrument) with a crossbar speed of $1 \mathrm{~mm} / \mathrm{min}$. The modulus of rupture (MOR) was calculated for each sample (ASTM C 133). In pressed, extruded and laminated samples, loading in the perpendicular direction was chosen for the bending tests. To achieve good statistics, a minimum set of five samples for each conformation process was used. Porosimetry was carried out by the method of mercury intrusion (Carlo Erba, Macropore 120 and Porosimeter 2000) and was conducted in a pressure range of 0.0 to $200.6 \mathrm{MPa}$; sintering conditions of samples chosen for the test were $1300{ }^{\circ} \mathrm{C}$ because of the results evaluated at this sintering temperature. The sintered ceramics were also observed on scanning electron microscope (SEM, Jeol, JCM 6000) and tomograph (Bruker, Skyscan 1173).

\section{RESULTS AND DISCUSSION}

Textural properties and shrinkage: the evolution of the apparent density as a function of temperature for the different conformations can be observed in Fig. 1. The green density $\left(110^{\circ} \mathrm{C}\right)$ presented the highest value for pressed samples, which had the least amount of water through the conformation. This was followed by extruded and laminated samples and finally the slip casting, which needed a dispersed liquid medium for shaping. Compaction of the particles in the forming process affects the degree of contact among them at the beginning of the sintering, revealing higher green density. At low sintering temperatures $\left(1100\right.$ and $\left.1200{ }^{\circ} \mathrm{C}\right)$, pressed sample presented the highest density and the slip casting sample presented the lowest. This result may be caused by the restructuring processes during the consolidation of the slurry in the slip casting process that leads to inhomogeneity of the ceramic body with the consequent lower density [10]. The maximum density was observed at $1200^{\circ} \mathrm{C}$ for the four shaped ceramics; this behavior was also achieved in [16] where the deformation after sintering of porcelain obtained by wet and dry processing was studied. Also pressed sample presented greater densification than extruded one. This behavior might be due to the pressure involved during the processing of the raw materials as reported in [8]. At 1300$1400{ }^{\circ} \mathrm{C}$ change in the density value for the four shaped ceramics was not observed. However, small differences were found in slip casting sample, which had a minor higher density than the other ones.

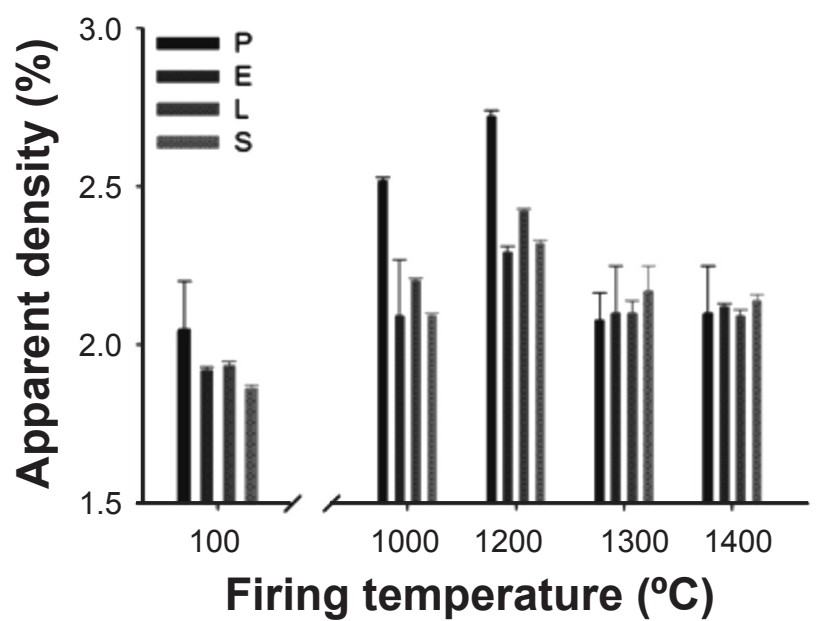

Figure 1: Apparent density of shaped ceramics: P - pressed, E - extruded, L - laminated, S - slip casting.

[Figura 1: Densidade aparente das cerâmicas conformadas: $P$ - prensada, E - extrudada, L - laminada, $S$ - colada.]

Table II shows the relative densification for the four shaping methods at the four temperatures, obtained by the relation of density in the different sinterering temperatures and the green state. The densification behavior in ceramics is probably due to viscous flow mechanism which begins at a critical temperature (around $1050^{\circ} \mathrm{C}$ ) and follows a growing trend in apparent density. In the final stage of sintering, the densification rate is contracted by coarsening phenomena, lowering the previously density reached [17]. In the two last sintering temperatures $\left(1300\right.$ and $\left.1400{ }^{\circ} \mathrm{C}\right)$, a drop in the densification percentage is observed (Table II). Decay for pressing is the highest, from $32.6 \%$ to $1.5 \%$, being this possible due to density gradients generated as the clay is compacted by the distribution of applied load in the pressed samples [18-20].

The evolution of the apparent open porosity as a function of temperature is shown in Fig. 2. At $110^{\circ} \mathrm{C}$ this property was lower for the pressed samples and higher for the slip casting ones. This trend was maintained at $1100{ }^{\circ} \mathrm{C}$, showing the effect of the densification percentage for pressed sample, having the highest value of $22.9 \%$ (Table II). At $1200{ }^{\circ} \mathrm{C}$ pressed sample presented the lowest value of porosity (1\%) and the highest value of densification rate $(32.6 \%)$. The minimum porosity for the four shaped ceramics was

Table II - Relative densification values in sintered ceramics. [Tabela II - Valores de densificação relativa em cerâmicas sinterizadas.]

\begin{tabular}{ccccc}
\hline $\begin{array}{c}\text { Shaped } \\
\text { ceramic }\end{array}$ & \multicolumn{5}{c}{ Densification (\%) } \\
\hline Pressed & 22.9 & 32.6 & 1.5 & 2.4 \\
Extruded & 8.8 & 19.3 & 9.3 & 10.4 \\
Laminated & 13.9 & 25.3 & 8.8 & 8.3 \\
Slip casting & 12.3 & 24.7 & 16.6 & 15.1 \\
\hline
\end{tabular}


obtained at $1300{ }^{\circ} \mathrm{C}$; this can be explained because the sintering occurs with a large amount of liquid phase, which controls densification rate and closed porosity [17]. In the liquid phase sintering, progressive closure of the capillaries forming open porosity is occurring, and an increment of closed porosity with a smaller pore size begins [9]. The low density and densification percentage at this temperature can be explained by the presence of a greater amount of vitreous phase with a lower density than crystalline phases. All shaped samples behaved equally, regardless the initial density and porosity. It is possible that the pressed sample started this closing process before, since it had the highest densification rate (Table II). At $1400{ }^{\circ} \mathrm{C}$ an increment in open porosity occurred; this is probably because the temperature increase may induce overfiring effects, leading to bloating [17]. At this temperature, slip casting sample had the minimum increment of porosity, and extruded sample presented the maximum increment of porosity (with a leap of about 5\%).

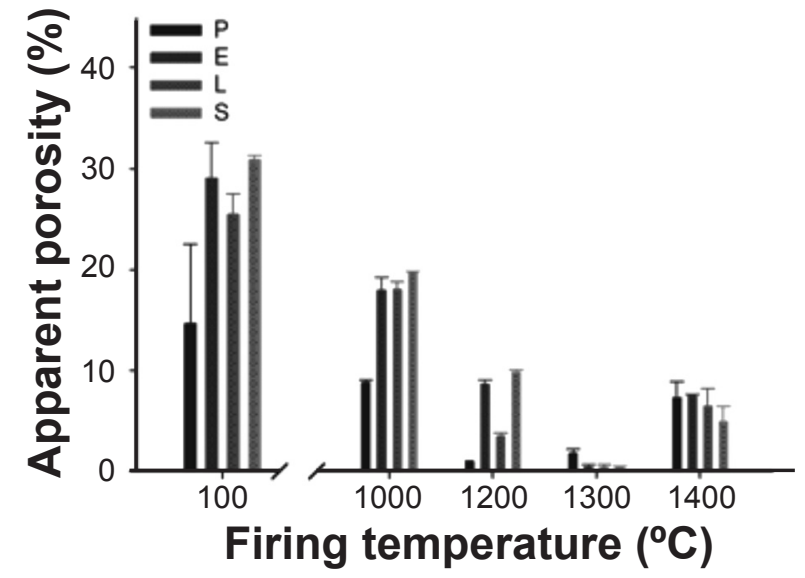

Figure 2: Apparent porosity of shaped ceramics.

[Figura 2: Porosidade aparente das cerâmicas conformadas.]

The evolution of the ceramics shrinkage as a function of temperature is shown in Fig. 3. At $1100{ }^{\circ} \mathrm{C}$ pressed sample had the higher shrinkage value; this could be because of the higher densification at this sintering condition. Slip

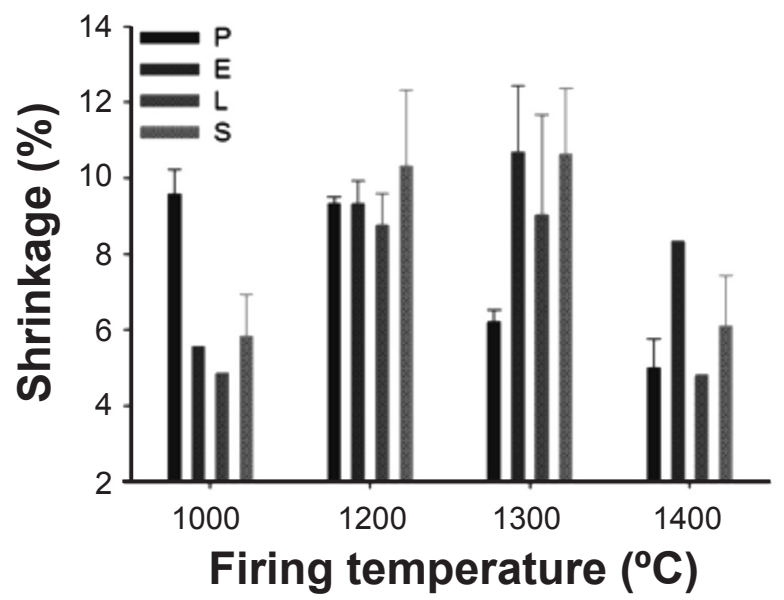

Figure 3: Shrinkage of the ceramic largest dimension. [Figura 3: Retração da maior dimensão da cerâmica.] casting sample presented the lower shrinkage, reversing this behavior at $1300{ }^{\circ} \mathrm{C}$, where its densification had the highest value compared to the other shaping methods (Table II). The shrinkage began to decline from 1300 to $1400{ }^{\circ} \mathrm{C}$ for all shaped ceramics; this is attributed to the decay of densification rate leading to bloating effects [17] and formation of mullite phase at high temperature [21].

The pore size distribution for the four conformations, sintered at $1300{ }^{\circ} \mathrm{C}$ is presented in Fig. 4. This temperature was chosen because is the sintering condition where the porosity was minimum (Fig. 2). Fig. 4 shows data that were cumulated from largest pore diameter measured to the smallest diameter (limited set by the pressuring capacity of the instrument). The advantage of using the cumulative function is that the fraction of pore space between bounds of pore size can be calculated directly [22]. For pressed sample, the intrusion of mercury took place over a considerably greater range of pores. The curve started at about $10000 \mathrm{~nm}$ and appeared to be considerably more open. The total pore space was $31 \mathrm{~mm}^{3} / \mathrm{g}$ (all which was intruded by mercury) and appeared that about $50 \%$ of the pore space present was in a diameter greater than $1000 \mathrm{~nm}$. For slip casting sample, it was apparent that the bulk of open pores was in a diameter within a narrow range of about 70 to $1000 \mathrm{~nm}$. Both pressed and slip casting samples, no open pores finer than about $70 \mathrm{~nm}$ diameter were presented. By comparing the conformation process of pressing and slip casting, and considering that the first process required less moisture than the second one, the poor mobility of the liquid vitreous phase during sintering through the compact structure of the first process means that the penetration into grain boundaries for reaching pore is being reduced, and this may generate the increment in the pore size [16]. Extruded and laminated samples showed as much as $1 \mathrm{~mm}^{3} / \mathrm{g}$ of pore space intruded in the range between limits of about 10000 and $100 \mathrm{~nm}$.

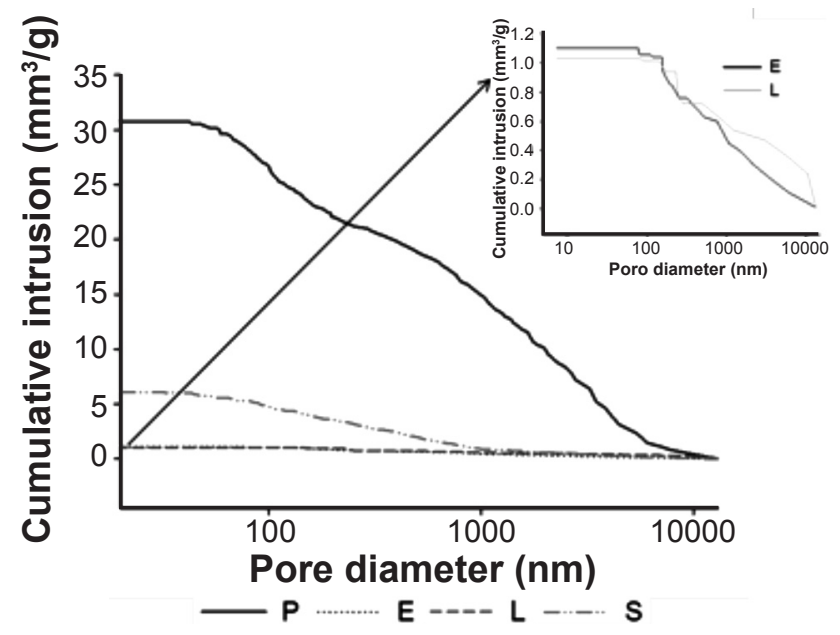

Figure 4: Porosimetry of shaped ceramics sintered at $1300{ }^{\circ} \mathrm{C}$. [Figura 4: Porosimetria de cerâmicas conformadas e sinterizadas a $1300{ }^{\circ} \mathrm{C}$.]

$X$ ray diffraction analysis: Table III shows a semiquantitative analysis by Rietveld method of the different 
Table III - Crystalline phase contents (wt\%) in shaped ceramics sintered at $1300{ }^{\circ} \mathrm{C}$.

[Tabela III - Teores de fases cristalinas (\% em massa) em cerâmicas conformadas e sinterizadas a $1300{ }^{\circ} \mathrm{C}$.]

\begin{tabular}{cccccc}
\hline Shaped ceramic & Quartz & Mullite & Cristobalite & Corundum & Non-crystalline phase \\
\hline Pressed & $3.10 \pm 0.04$ & $44.23 \pm 0.10$ & $5.23 \pm 0.04$ & $15.06 \pm 0.03$ & $32.38 \pm 0.09$ \\
Extruded & $3.11 \pm 0.01$ & $39.38 \pm 0.06$ & $4.46 \pm 0.03$ & $15.63 \pm 0.04$ & $37.42 \pm 0.07$ \\
Laminated & $3.54 \pm 0.04$ & $36.42 \pm 0.10$ & $3.74 \pm 0.03$ & $16.88 \pm 0.04$ & $39.43 \pm 0.08$ \\
Slip casting & $2.81 \pm 0.01$ & $41.18 \pm 0.06$ & $4.00 \pm 0.03$ & $15.62 \pm 0.04$ & $36.39 \pm 0.07$ \\
\hline
\end{tabular}

crystalline phases present in the four studied shaped materials sintered at $1300{ }^{\circ} \mathrm{C}$. The breakdown of clay minerals and the formation of vitreous phase start from about $1050{ }^{\circ} \mathrm{C}$, and leads to the progressive formation of amorphous components and mullite [17]. The results showed a greater mullite formation in pressed samples. It is important for solid state reactions that ceramic presents high green density, because its particles are then in closer contact [23]. The fact that lamination and extruding processes have exhibited the lowest values of mullite showed that their low green density reduced the contact area among the particles and in consequence presented a lower sintering reaction progress. Following the tendency of the reaction progress in the sintering process governed by the initial degree of contact among particles in the green body, technique of pressing had the greatest percentage of the mullite and cristobalite phase, and the lowest percentage of the unreacted alumina phase, which was followed by the extruding, slip casting and finally lamination processes. The laminated sample presented the highest percentage of noncrystalline phase, followed by extruded, slip casting and finally pressed ones (Table III).

Mechanical strength of sintered ceramics: the bending strength behavior (MOR) of the four shaped samples as a function of temperature is shown in Fig. 5. Pressed sample at low sintering temperature started with the highest MOR, probably due to its highest densification value (Table II), and then no significant change of the MOR was observed for this sample. At $1200{ }^{\circ} \mathrm{C}$ the highest MOR was presented

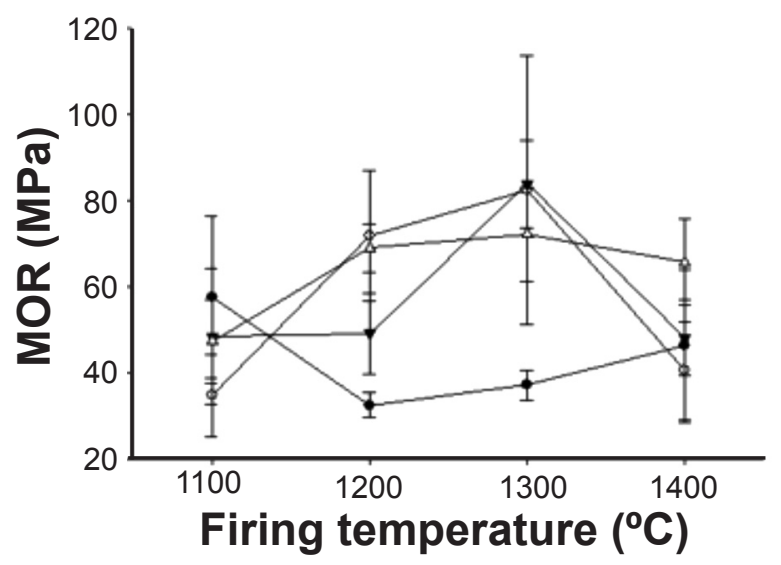

$\rightarrow$ pressing process -o- extruding process

$\neg$ laminating process $\rightarrow-$ slip casting process

Figure 5: Bending strength, MOR, of sintered samples.

[Figura 5: Resistência à flexão, MOR, de amostras sinterizadas.]
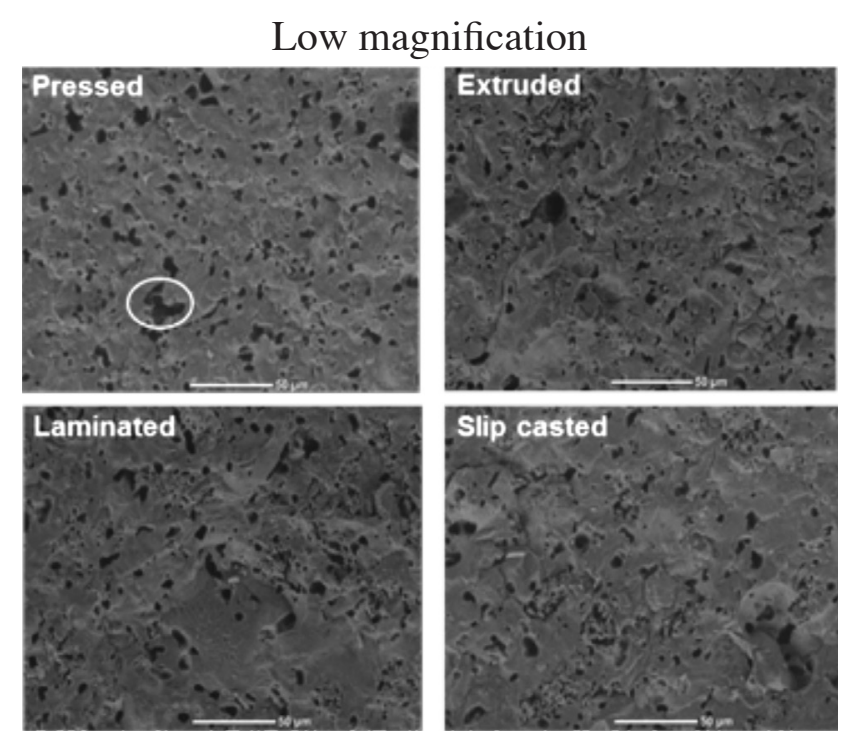

High magnification
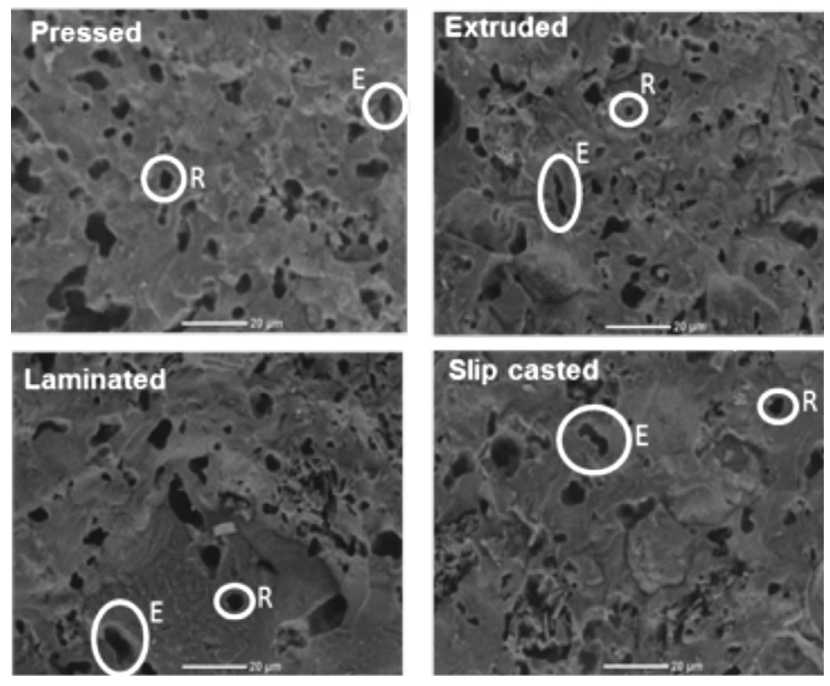

Figure 6: SEM images of the four shaped ceramics sintered at $1300{ }^{\circ} \mathrm{C}$.

[Figura 6: Micrografias obtidas por microscopia eletrônica de varredura das quatro cerâmicas conformadas e sinterizadas a $\left.1300{ }^{\circ} \mathrm{C}.\right]$

by slip casting and extruded samples. The maximum MOR values for extruded, laminated and slip casting samples were at $1300{ }^{\circ} \mathrm{C}$, with a smaller value for the last one. The behavior for laminated and slip casting samples can be explained because at this temperature the highest MOR was presented for the shaped ceramic with the highest percent 

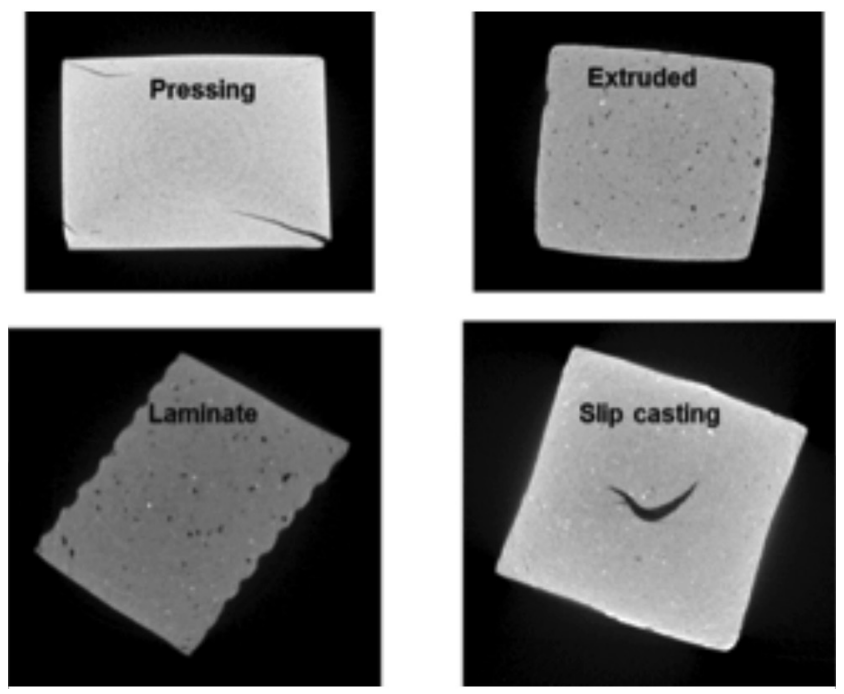

Figure 7: Transversal tomographic images of shaped ceramics sintered at $1300^{\circ} \mathrm{C}$.

[Figura 7: Imagens tomográficas transversais de cerâmicas conformadas e sinterizadas a $1300{ }^{\circ} \mathrm{C}$.]

of vitreous phase (Table III), which was laminated sample. Lowest MOR was presented for the shaped ceramic with the minimum percentage of vitreous phase (Table III), which was slip casting sample. There are previous studies done about the correlation between the bending strength and the vitreous phase content, where it is maintaining standarddeviation that is inherent to ceramic materials $[10,13,24$, 25]. At $1400{ }^{\circ} \mathrm{C}$ bending strength decreased abruptly for extruded and laminated samples. For slip casting sample, bending strength among 1200,1300 and $1400{ }^{\circ} \mathrm{C}$ showed slight variations.

Microstructure analysis, scanning electron microscopy (SEM) and X-ray microtomography: by observing the fracture surface of the sintered samples at $1300{ }^{\circ} \mathrm{C}$ using SEM (Fig. 6), it could be seen that the actual fracture propagation was intragranular. Regarding the amount of size distribution of pores, the applied pressure while the clay is shaped gives different pore size and morphologies [26]. In pressed sample, it could be seen the shape of the pores rounded and elongated, and the average size was between 2 and $15 \mu \mathrm{m}$ for the rounded ones and 6 to $10 \mu \mathrm{m}$ for the elongated ones. The occurrence of pore junctions was also observed, revealing the fast sintering process. In extruded sample rounded and elongated pores could be seen, and the average pore size was between 2 and $10 \mu \mathrm{m}$. Also, some larger pores could be observed and this may be produced by air, which could not be evacuated and remained in the paste during extrusion. The laminated sample presented rounded and elongated pores, with pore size between 2 and $10 \mu \mathrm{m}$ for the rounded ones and 10 to $15 \mu \mathrm{m}$ for the elongated ones. The slip casting sample showed rounded and elongated pores, and the average pore size was between 2 and $8 \mu \mathrm{m}$ for the rounded ones and 10 to $15 \mu \mathrm{m}$ for the elongated ones.

Some tomographic views (Fig. 7) of the shaped ceramics sintered at $1300^{\circ} \mathrm{C}$ allow macro-optic images of the ceramic matrix, and observation of its defects. The ceramics used for observation were not used as sample test. As the pressed sample had the highest degree of compaction it presented visible cracks on both sides of load application, acting as a beginning of fracture. For extruded and laminated samples, a porous matrix was observed. Moreover, a dense material is hard to reach with these two processes. Slip casting sample presented a central hollow after sintering, possibly because in the conformation process the center of the mold is where the maximum water absorption through plaster walls occurs.

\section{CONCLUSIONS}

Four typical conformation techniques for ceramic materials were studied. The sintering behavior was analyzed and final mechanical properties were compared. Apparent densities were maximum at $1200{ }^{\circ} \mathrm{C}$ for all the shaping methods, being highest for pressed samples. The apparent porosity was minimum at $1300{ }^{\circ} \mathrm{C}$ for the four shaped ceramics. Pressed sample, sintered at $1300{ }^{\circ} \mathrm{C}$, presented the highest open pore space intruded by mercury. Slip casting sample presented a narrow pore size distribution. Extruding and lamination processes resulted the lowest open pore space while no significant difference was observed in SEM images of the four shaped ceramics with respect to the total volume space of pores. This is possibly due to a higher volume of closed pores. Tomographic images revealed large pores in these extruded and laminated ceramics. SEM images showed differences in pore distribution for each conformation process; all fracture propagations were intragranular. Extruded and laminated samples with the highest percentages of vitreous phase had the highest mechanical strength at $1300{ }^{\circ} \mathrm{C}$. The pressing process achieved the highest green density, which indicated promotion of a high degree of contact between particles and a high mullite reaction after sintering. Extruded and laminated samples had low initial density, so contact between particles was lower. This reduced the sintering reaction, resulting in the lowest values of mullite formation. The slip casting process presented intermediate values of mullite and vitreous phase. Experimental results indicated a good mobility of the liquid phase through the slip cast matrix while the sintering process was underway.

\section{ACKNOWLEDGMENTS}

This work has been partially supported by FONARSEC Project Nano-Petro 2012, granted by Agencia Nacional de Promoción Científicas y Tecnológica (ANPCyT), República Argentina. CI Torres worked under a research fellowship granted by CONICET and YPF Tecnología S.A. (Argentina).

\section{REFERENCES}

[1] V. Beltran, E. Sanchez, J. García, F. Ferrando, Tile Brick Int. 12 (1996) 320.

[2] O. Delbrouck, J. Janssen, R. Ottenburgs, P. Van Oyen, W. Viaene, Appl. Clay Sci. 8 (1993) 187. 
[3] M.S. Conconi, M.R. Gauna, M.F. Serra, G. Suarez, E.F. Aglietti, N.M. Rendtorff, Cerâmica 60 (2014) 524.

[4] S. Kitouni, A, Harabi, Cerâmica 57 (2011) 453.

[5] O. Castelein, B. Soulestin, J.P. Bonnet, P. Blanchart, Ceram. Int. 27 (2001) 517.

[6] E.A. Mari, The ceramic materials, Alsina, Buenos Aires (1998).

[7] M. Tecilazic-Stevanovic, T. Janackovic, L.J. KosticGvozdenovisc, in Proc. $3^{\text {rd }}$ CIMTEC, Rimini, Italy (1976) 339.

[8] M.T. Cotes, C. Martinez, F.J. Iglesias, F.A. Corpas, Bol. Soc. Esp. Ceram. V. 52 (2013) 169.

[9] M. Romero, J.M. Pérez, Mater. Constr. 65, 320 (2015) $\mathrm{e} 065$.

[10] M.J. Ribeiro, D.U. Tulyaganov, M.F.J. Ferreira, J.A. Labrincha, J. Mater. Proc. Technol. 148 (2004) 139.

[11] G.P. Souza, R. Sanchez, J.N.F. de Holanda, Cerâmica 48 (2002) 102.

[12] S.R. Teixeira, S.A. de Souza, C.A.I. Moura, Cerâmica 47 (2001) 204.

[13] C. Manoharan, P. Sutharsan. S. Dhanapandian, R. Venkatachalapathy, Cerâmica 58 (2012) 412.

[14] A.E. Soauza, S.R. Teixeira, G.T.A. Santos, E. Longo, Cerâmica 59 (2013) 147.

[15] B. João, R. Neto, R. Moreno, Appl. Clay Sci. 38 (2008)
209

[16] L.R.S. Conserva, F.G. Melchiades, S. Nastri, A.O. Boschi, M. Dondi, G. Guarini, M. Raimindo, C. Zanelli, J. Eur. Ceram. Soc. 37 (2016) 333.

[17] C. Zanelli, M. Raimondo, G. Guarini, M. Dondi, J. Non-Cryst. Solids 357 (2011) 3251.

[18] S.J. Glass, K.G. Ewsuk, MRS Bull. 22 (1997) 24.

[19] T. Garino, M.J. Readey, F.M. Mahoney, K.G. Ewsuk, J. Gieske, G.R. Stoke, Int. SAMPE Tech. Conf. No. 27 (1995) 610.

[20] F.M. Mahoney, M.J. Readey, Int. SAMPE Tech. Conf. No. 27 (1995) 645.

[21] H. Schneider, S. Komarneni, Mullite, Wiley-VCH, Weinheim (2005).

[22] S. Diamond, Clays Clay Miner. 18 (1970) 7.

[23] A. Roosen, H.K. Bowen, J. Am. Ceram. Soc. 71 (1988) 970.

[24] S.K. Hubadillah, Z. Harun, M.H.D. Othman, A.F. Ismail, P. Gani, J. Asian Ceram. Soc. 4 (2016) 164.

[25] J.M. Amigó, J.V. Clausell, V. Esteve, J.M. Delgado, M.M. Reventós, L.E. Ochando, T. Debaerdemaeker, F. Martí, J. Eur. Ceram. Soc. 24 (2004) 75.

[26] Y. Klemm, H. Biermann, C.G. Aneziris, Ceram. Int. 39 (2013) 6695.

(Rec.04/04/2017, Rev. 10/07/2017, Ac. 21/08/2017) 